\title{
Aeolian Sand Deposit Assessment in an Arid Area, Case Study: The Region of Ksour Mountains (SW of Algeria)
}

\section{Said Bouarfa}

Centre de Recherche Scientifique et Technique sur les Regions Arides

Abdessamed Derdour ( $\nabla$ derdour@cuniv-naama.dz )

Centre Universitaire de Naama https://orcid.org/0000-0002-1746-1765

\section{Youb Okkacha}

Centre de Recherche Scientifique et Technique sur les Regions Arides

Abdulrazak H. Almaliki

Taif University

Antonio Jodar-Abellan

University of Granada: Universidad de Granada

Enas E. Hussein

National Water Research Center Nile Research Institute

\section{Research Article}

Keywords: Aeolian sand deposit, Ksour Mountains, Ain Sefra, Granulometry, Calcimetry, Morphoscopy

Posted Date: January 31st, 2022

DOI: https://doi.org/10.21203/rs.3.rs-1234507/v1

License: (c) (i) This work is licensed under a Creative Commons Attribution 4.0 International License. Read Full License 


\section{Abstract}

The phenomenon of aeolian sand deposit constitutes a major problem in the region of Ksour Mountains in Algeria, which causes serious social and economic problems. To assess the textural properties of sands, and to investigate the origin of aeolian sand deposit in the study area, eleven (11) samples were collected from the sands of Ain Sefra. Then the granulometry, calcimetry and morphoscopy of the samples were studied. Granulometric testing of samples from 11 locations showed that sand size was very fine to fine grained, with a mean grain value of $226.5 \mu \mathrm{m}$. It sort ranged from 1.22 to 1.90 , indicating well sorting the sands and skewness values ranging from-0.4 to 0.66 , being mainly negative with an average of -0.06 , indicating symmetrical to fine skewed values. The values of kurtosis ranges from 0.79 to 1.5 , with an average of 0.93 , where 64 percent of samples are Mesokurtotic and 36 percent of samples are Platikurtotic. Calcimetric results show a very low percentage of carbonate, which ranges from $1.85 \%$ to $7.4 \%$ and illustrate a very low content of fine fraction and organic matter. The preliminary examinations of the sands in our study area by morphoscopy showed that 73 percent of sand are in RM category, 19 percent in the rounded and shiny (EL) category. In comparison, 08 percent are represented by the fresh and angular (NU) category. The outcome of various experimentation led to the conclusion that the aeolian sand deposit in the study area, are linked to the wind transport from the Moroccan territory such as Chott Tigri, Oued Maader, the corridor between Figuig, Bouarfa and Massa Daraa, which are the dominant sources of sands in the region of the study area. Therefore, the study better understands the origin of sands and their characteristics in this part of the Ksour Mountains.

\section{Introduction}

With an increasing danger of aeolian sand migrations from different sources, it is essential to bear in mind how the present sands environment is emerging under human and natural pressures. Aeolian sands have been studied in various fields in the earth and sciences. Early scientific works on the geological origin of aeolian sands have been reported, referring to their physical, chemical, mineralogical, and morphological features.

Blake (1855) was one of the first to notice the extensive development of wind erosion forms in the Sahara, and von Richthofen (1882) identified the fundamental aeolian origin of the huge loess deposits that cover much of northern side of China. Then, there was a surge in interest in aeolian processes in the late nineteenth century and the twentieth century, and some very descriptive references were produced (Beadnell, 1909; McKee, 1979; Pease et al., 1999; Zhu, 1985). Recently, a diversity of research on aeolian sands characterization, the same as approaches to reduce its movement, has been published worldwide (Baratoux et al., 2011; Barrena-González et al., 2020; Bertran et al., 2021; Chojnacki et al., 2020; Fotoohi et al., 2022; Han et al., 2012; Hereher, 2018; S. Liu et al., 2021; X.-J. Liu et al., 2019; Tian et al., 2019; Veit et al., 2015; Wolfe \& Lian, 2021). Otherwise, it should be noted that an important lack of scientific studies covering the paper's topic in arid areas, such as Algeria, was identified.

In Algeria, sand dunes serve as one of the country's most prominent geomorphological features in the Sahara, where roughly 20 million hectares are threatened by wind erosion. Algeria's arid regions are known for their fragile ecosystems. They are the main areas affected by Aeolian sand deposits (Nedjraoui \& Bédrani, 2008). The arid and steppe areas, constantly affected by the winds, are located in the southwestern part of Algeria and the Saharian Atlas. In this region, there are sandy currents formed by long bands of dunes that are oriented from the southwest (SW) to the northeast (NE) (Nedjraoui \& Bédrani, 2008). Aeolian sand migrations do not proceed from a continuous and single movement to the final deposition zone in arid environments. These sandy migrations act by continuously recycling the sand passing through the wadis, spread by the latter at the outlet of a plain, picked up by the wind before accumulating again (Benazzouz, 2003). The wind is the focal component responsible for the transport and deposition of sand sediments and landform modeling (Abuzaid et al., 2021; Mainguet, 2012). Speed, direction, magnitude and frequency are the main elements of wind that define its efficiency. However, only strong winds that reach the threshold speed can have erosive 
activity. Three sands types are distinguished, autochthonous and allochthonous, which provide information about past environmental change in the surrounding watershed. Depending on their importance, these types are either transitional or form dunes. A few studies have been reported recently to assess aeolian sands deposit in Algeria. Benazzouz (2003) studied the aeolian sands mineralogy in the Zibans range in the south of Algeria. Boureboune and Benazzouz (2009) carefully designed to combat the desertification in Zibans and Hodna basin in Algeria. Boulghobra (2016) used satellite imagery and climatic data to assess the aeolian sand deposit in the region of In-Salah in the south of Algeria.

Boulghobra et al. (2016) investigated the aeolian risk in the Touggourt region situated in the south of Algeria. Bouarfa and Bellal (2018) investigated the concentration of sand buildup beneath Algeria's western mountain foothills between 1985 and 2015. All this previous research provided in Algeria, focused mostly on the desert domain, with no studies have been conducted to determine the Aeolian sand deposits in our study area. This research aims to learn more about the textural properties of sand dunes in the region of Ksour Mountains and particularly the region of Ain Sefra and to investigate the source of aeolian sand deposits in this part of Ksour Mountains. This research could help us better understand the factors that influence the shape and size of dunes and the methods in which eolian sand bodies accumulate.

\section{Materials And Methods}

\subsection{Geographical context}

The Ain Sefra is part of the Ksour Mountains, and it covers about $3851 \mathrm{Km} 2$. It is situated in the southwest of Algeria, it's limited to the north by Chott-Chergui and Chott-Gharbi watersheds, to the west by Morocco, to the south by the region of Bechar, and to the east by El-Bayadh (Fig. 1). This arid region is surrounded by mountains, where the altitude of some summits can reach 2000 m, such as Djebel Aissa (2236 m), Djebel Mzi (2187 m), Djebel Morghad (2136 m), Mir El djebel (2109 m), and Djebel Mekther (2035 m) (Derdour \& Bouanani, 2019). The meteorological data of 30 years (1985-2015) gathered from Ain Sefra weather station by Bouarfa and Bellal (2018) revealed that the average precipitation is about $196.73 \mathrm{~mm}$ with strong seasonal and annual variations. The annual average number of rainy days is 55 days, and the annual average temperature is $17.79^{\circ} \mathrm{C}$. The south sector and west-southwest winds are effective and able to cause movement of sands according to the annual wind rose, where the more frequent winds are between 4 and $6 \mathrm{~m} / \mathrm{s}$. Furthermore, according to the effective wind threshold speed, sand movement quantity is between 23.03 and 15,224 m3/m/year. The soils are shallow and less fertile, with an organic matter level that does not exceed 3 percent (Aidoud \& Touffet, 1996). From a geological standpoint, the geological series of the region range from the Triassic to the recent Quaternary, and the geological facies that dominate the region are Jurassic and Pliocene sandstones and limestones (Derdour et al., 2021). The analysis of the land use revealed that the forests represent 7.05 percent of the surface of the study area, the rocky outcrops represent 15.06 percent, the very degraded ranges represent 24.06 percent, the steppe ranges represent 29.14 percent, the wind accumulations represent about 17.94 percent, and the sand dunes represent only 6.74 percent (Derdour et al., 2018). The region of Ain Sefra suffers from serious environmental problems linked to wind erosion and dune migration which further accelerate the process of desertification (Fig. 2).

\subsection{Data acquisition.}

In our study area, eleven (11) samples were collected for granulometry, calcimetry, and morphoscopy analyses to cover all the watershed (E01-E02- E03 E04 -E05-E06- E07-E08-E09-E10-E11), as shown in Table 1 and Fig. 3. In fact, on each side, the most representative dunes were the subject of sand samples $(500 \mathrm{~g})$ taken from their crest. And on a dune of each site, we sampled on the right and left toes, on the middle of the right and left flanks (Fig. 4), on sand accumulations, and on the sands inside the city of Ain Sefra. All Samples of sands were taken simultaneously with 
wind measurements made at the same height as the samples. It is to find a correlation between the particle size of the moving sand and the wind speed and compare them to the sand taken in this position.

Table 1

Samples distribution in the watershed of Ain Sefra.

\begin{tabular}{|c|c|c|c|}
\hline Sample & Y LAT & X LONG & Position \\
\hline E01 & $32^{\circ} 44^{\prime} 8.98^{\prime \prime} \mathrm{N}$ & $0^{\circ} 34^{\prime} 18.20 " \mathrm{~W}$ & Right dune toe \\
\hline E02 & $32^{\circ} 43^{\prime} 44.99^{\prime \prime} \mathrm{N}$ & $0^{\circ} 34^{\prime} 54.26 " \mathrm{~W}$ & Right dune flank \\
\hline E03 & $32^{\circ} 43^{\prime} 43.74 " \mathrm{~N}$ & $0^{\circ} 35^{\prime} 55.19 " \mathrm{~W}$ & Sand accumulations \\
\hline E04 & $32^{\circ} 43^{\prime} 12.36 " \mathrm{~N}$ & $0^{\circ} 35^{\prime} 47.23^{\prime \prime} \mathrm{W}$ & Crest of dune \\
\hline E05 & $32^{\circ} 45^{\prime} 18.24 " \mathrm{~N}$ & 0॰36'39.97"W & Sands inside the city of Ain Sefra \\
\hline E06 & $32^{\circ} 42^{\prime} 51.85^{\prime \prime} \mathrm{N}$ & 0³6'33.29"W & Left dune toe \\
\hline E07 & $32^{\circ} 41^{\prime} 32.02^{\prime \prime} \mathrm{N}$ & $0^{\circ} 36^{\prime} 52.34 " \mathrm{~W}$ & Right dune toe \\
\hline E08 & $32^{\circ} 42^{\prime} 6.53^{\prime \prime} \mathrm{N}$ & $0^{\circ} 37^{\prime} 10.46 " \mathrm{~W}$ & Left dune flank \\
\hline E09 & $32^{\circ} 42^{\prime} 20.68^{\prime \prime} \mathrm{N}$ & $0^{\circ} 40^{\prime} 40.67 " \mathrm{~W}$ & Sand accumulations \\
\hline E10 & $32^{\circ} 42^{\prime} 24.30^{\prime \prime} \mathrm{N}$ & $0^{\circ} 36$ '39.65"W & Crest of dune \\
\hline E11 & $32^{\circ} 47^{\prime} 57.41^{\prime \prime} \mathrm{N}$ & $0^{\circ} 36^{\prime} 13.86^{\prime \prime} \mathrm{W}$ & Sands in the city of Ain Sefra \\
\hline
\end{tabular}

\subsection{Granulometric analysis}

For this research, the granulometric examination was carried out according to the classical method described by Berthois (1959) and Verger (1963) in relation to the AFNOR standards (AFNOR, 2018). The samples were rinsed, dried in an oven, weighed, and sieved on a column of twelve sieves with mesh sizes ranging from $500 \mathrm{~m}$ to $0.63 \mathrm{~m}$ for twenty minutes. The purpose is to create particle size curves (frequency, cumulative) and calculate particle size characteristics that provide information on the degree of sediment categorization, such as mean, sorting (standard deviation), skewness, Kurtosis and standard deviation. These parameters can be calculated by using the software of GRADISTAT developed by Blott and Pye (2001). The semilogarithmic particle size curves' form enables for the identification of different particle size facies, then interpreted according to the work of Folk and Ward (1957) who used different percentiles in $\varphi$-units: $\varphi 50$ (the median), $\varphi 16$ and $\varphi 84$ (the percentiles at the points of curvature of a Gaussian distribution). The Median corresponds to the 50percent of the total frequency, and this parameter characterizes the coarseness of the sediment (Trask, 1931; Wu et al., 2021). The analyzes were carried out in the Laboratory of Eremology and Combating Desertification (IRA) of Medenine in Tunisia. Table 2. Show the size scale adopted in the GRADISTAT program, used in the discussion section. 
Table 2

Size scale adopted in the GRADISTAT

software, adapted form Udden (1914) and

Wentworth (1922).

\begin{tabular}{|ll|}
\hline Grain size $(\boldsymbol{\mu m})$ & Descriptive term \\
\hline $1000-2000$ & Very Coarse Sand \\
\hline $500-1000$ & Coarse \\
\hline $250-500$ & Medium \\
\hline $125-250$ & Fine \\
\hline $63-125$ & Very fine \\
\hline $31-63$ & Very Coarse Silt \\
\hline $16-31$ & Coarse \\
\hline $8-16$ & Medium \\
\hline $4-8$ & Fine \\
\hline $2-4$ & Very Fine \\
\hline $0-2$ & Clay \\
\hline
\end{tabular}

\subsection{The calcimetric determination}

The calcimetric determination (CaCO3) was carried out using the Bernard Calcimeter Method which allows the identification of carbonate levels in the sediments. The analyzes were carried out in the Laboratory of Eremology and Combating Desertification (IRA) of Medenine in Tunisia. This analysis allows establishing the detrital or bio detrital origin of the sediments. Various scientists have researched and developed this method (Hulseman, 1966; Muller \& Gatsner, 1971). The assay estimates the CO2 produced when a sample of soil or rock is treated with hydrochloric acid $(\mathrm{HCl})$ on the calcium carbonate $(\mathrm{CaCO} 3)$. This principle is well known for laboratory tests. This calcium carbonate and hydrochloric acid reaction is a total and exothermic reaction releasing carbon dioxide (CO2). Eq. 1 obtains the percentage of carbonates:

$\% \mathrm{CaCO}_{3}=\frac{V_{1}}{V_{0}} \times 100(1)$

\subsection{Organic matter content}

Stable organic matter in soil results from the gradual decomposition of crop residues, and plants, animals and other living biological organisms in the soil. The organic matter content of a soil is determined indirectly, from the determination of the organic carbon content, according to the international standard method NF ISO 14235 (ISO, 1998). The organic matter (OM) rate is calculated by multiplying the organic carbon (OC) content by a stable coefficient in regional cultivated soils, set at 1.72, as mentioned in Eq. 2.

$O M \%=1.72 \times O C(2)$

\subsection{The morphoscopic determination}

Morphoscopy, which was determined by Ribault (1975), as being "the statistical determination of the different types of quartz in sandy deposits", the proportions of each type and the variations of these proportions during transport. Then during these counts, the most representative particles were selected to be observed with a Scanning Electron 
Microscope (SEM). The morphoscopic assessment of the sand grains in this zone also provides information on their deposit habitats, transport conditions, and environmental effect. The analyzes were carried out in the Scientific and Technical Research Center on Arid Regions (CRSTRA).

\section{Results And Discussion}

\subsection{Laboratory analyses}

The calcimetric study reveals the selective calcium loss from an impure parent limestone (Derdour et al., 2020). Eleven samples from the commune of Ain Sefra were calcimetrically analyzed (Table 3). The calcium carbonate concentration of these samples ranged from 1.85 percent in sample E04 to 7.4 percent in sample E01. Analysis of the calcimetric results shows a very low percentage of calcium carbonate content in the samples, which means that the samples have a low limestone content.

Table 3

Results of lime content in the samples.

\begin{tabular}{|lll|}
\hline Samples & $\mathrm{CaCO}_{3}$ percent & Observation \\
\hline E01 & 7.4 & Low carbonate content \\
\hline E02 & 3.7 & Very low carbonate content \\
\hline E04 & 3.7 & Very low carbonate content \\
\hline E05 & 1.9 & Very low carbonate content \\
\hline E06 & 7.0 & Low carbonate content \\
\hline E07 & 6.7 & Low carbonate content \\
E08 & 3.0 & Low carbonate content \\
\hline E09 & 3.3 & Very low carbonate content \\
\hline E10 & 1.9 & Very low carbonate content \\
\hline E11 & 5.9 & Very low carbonate content \\
\hline
\end{tabular}

Organic matter greatly enhances the cation exchange capacity of the soil and retains nutrients that plants can assimilate. Thus, organic matter constitutes a reservoir of slowly assimilable nutrients. As shown in Table 4, the analysis of the composition of the sandy material within the dune system of Ksour Mountains shows a very low content of fine fraction and organic matter (silt, clay and organic matter). However, this overall trend is interrupted in places. It may be related to the presence or absence of plant cover capable of providing organic matter and subsequently increasing the percentage of the fine fraction. 
Table 4

Organic matter content in the samples.

\begin{tabular}{|llll|}
\hline Samples & C percent & OM percent & Observation \\
\hline E01 & 0.56198347 & 0.96661157 & Very low organic matter content \\
\hline E02 & 0.09917355 & 0.17057851 & Very low organic matter content \\
\hline E03 & 0.42975207 & 0.73917356 & Very low organic matter content \\
\hline E04 & 0.42975207 & 0.73917356 & Very low organic matter content \\
\hline E05 & 0.16528926 & 0.28429753 & Very low organic matter content \\
E06 & 0.59504132 & 1.02347107 & Very low organic matter content \\
\hline E07 & 0.52892562 & 0.90975207 & Very low organic matter content \\
\hline E08 & 0.0661157 & 0.113719 & Very low organic matter content \\
\hline E09 & 0.46280992 & 0.79603306 & Very low organic matter content \\
\hline E10 & 0.39669421 & 0.68231404 & Very low organic matter content \\
\hline E11 & 0.1322314 & 0.22743801 & Very low organic matter content \\
\hline
\end{tabular}

The cumulative semi-logarithmic curves of the sands samples taken from our study presented in Fig. 5 show a sigmoidal (hyperbolic) type pattern. The curves have the shape of a "S "more or less spreading which indicates fine sands, which means that the sands are stretched, well classified with a well-developed rectilinear sector in its middle part more and more towards the east. This facies also indicates that the sands were transported in a more or less disturbed environment with fine particle evacuation.

Table 5 gives the complete information of measured and calculated values of different samples analyzed. Median results denote that at particular value of $\mathrm{d50}$, half of the particles are fine sands. Inclusive graphic median (d50). The values in our samples range from $197.3 \mu \mathrm{m}$ to $256.8 \mu \mathrm{m}$, averaging $228.3 \mu \mathrm{m}$ (Fig. 6-A). The mean values range from 201.5 to 245.5 , with an average of 226.5 which shows that the samples mostly belong to fine sands. These results are comparable with those given by the median. We noted that this average, in general, tends to decrease according to the position of the samples (Table 6). The measures of the sorting (Standard deviation) or uniformity of the grains indicating energy conditions that prevailed during transport and deposition. It ranges from 1.22 to 1.90, with an average of 1.31 (Fig. 6-B). This indicates the well-sorting of the sediments, according to the classification of Folk and Ward (1957). The majority of samples (08 samples) are very well sorted, representing smooth and stable currents, followed by moderately sorted species of 03 samples (E05, E07, E011) which can be attributed to slight variability in current velocity. The Skewness measures the degree of asymmetry in the frequency curves regarding the predominance of grains fractions. The kurtosis values range from 0.79 to 1.5 , with an average of 0.93 . Where 64 percent of samples are Mesokurtotic and 36 percent are Platikurtotic (Fig. 6-C). The skewness value in our samples ranges from -0.4 to 0.66 , with an average of -0.06 , ranging from near symmetrical to strongly fine skewed. According to the classification of Folk and Ward (1957), we remark that most of the samples are symmetrical, and the rest are coarse skewed and very fine skewed (Fig. 6-D). It shows the symmetry of the curves in the part of the dune system. It explains that the deposition of sediments takes place suddenly and without subsequent reworking by excess load and / or by a decrease in the competence of the carrier current. While in the other parts, the curves show an asymmetry towards the fine elements, with a negative asymmetry, which means that the sediments are deposited in a turbulent medium which deprives them of the fine elements which fill the void left between the coarse elements after disposal is the process of deflation, the main driving force behind aeolian sands deposits. 
Table 5

Granulometric parameters of sands in the study area.

\begin{tabular}{|c|c|c|c|c|c|c|c|c|c|}
\hline \multirow[b]{2}{*}{ Sample } & \multirow{2}{*}{$\begin{array}{l}\begin{array}{l}\text { Median } \\
\text { (d50) }\end{array} \\
\text { Value }\end{array}$} & \multicolumn{2}{|l|}{ Mean } & \multicolumn{2}{|c|}{ Sorting Index } & \multicolumn{2}{|c|}{ Skewkness } & \multicolumn{2}{|c|}{ Kurtosis } \\
\hline & & Value & Description & Value & Description & Value & Description & Value & Description \\
\hline E01 & 253.4 & 243.8 & Fine Sand & 1.23 & $\begin{array}{l}\text { Very Well } \\
\text { Sorted }\end{array}$ & -0.31 & $\begin{array}{l}\text { Very Fine } \\
\text { Skewed }\end{array}$ & 0.89 & Platykurtic \\
\hline E02 & 197.3 & 202.4 & Fine Sand & 1.25 & $\begin{array}{l}\text { Very Well } \\
\text { Sorted }\end{array}$ & 0.13 & $\begin{array}{l}\text { Coarse } \\
\text { Skewed }\end{array}$ & 0.99 & Mesokurtic \\
\hline E03 & 197.7 & 201.5 & Fine Sand & 1.24 & $\begin{array}{l}\text { Very Well } \\
\text { Sorted }\end{array}$ & 0.10 & Symmetrical & 1.01 & Mesokurtic \\
\hline E04 & 211.9 & 212.0 & Fine Sand & 1.22 & $\begin{array}{l}\text { Very Well } \\
\text { Sorted }\end{array}$ & 0.05 & Symmetrical & 0.89 & Platykurtic \\
\hline E05 & 235.9 & 239.0 & Fine Sand & 1.50 & $\begin{array}{l}\text { Moderately } \\
\text { Well Sorted }\end{array}$ & 0.02 & Symmetrical & 1.01 & Mesokurtic \\
\hline E06 & 256.8 & 241.2 & Fine Sand & 1.24 & $\begin{array}{l}\text { Very Well } \\
\text { Sorted }\end{array}$ & -0.40 & $\begin{array}{l}\text { Very Fine } \\
\text { Skewed }\end{array}$ & 0.79 & Platykurtic \\
\hline E07 & 245.1 & 245.5 & Fine Sand & 1.50 & $\begin{array}{l}\text { Moderately } \\
\text { Well Sorted }\end{array}$ & -0.02 & Symmetrical & 0.95 & Mesokurtic \\
\hline E08 & 197.3 & 203.4 & Fine Sand & 1.25 & $\begin{array}{l}\text { Very Well } \\
\text { Sorted }\end{array}$ & 0.13 & $\begin{array}{l}\text { Coarse } \\
\text { Skewed }\end{array}$ & 0.99 & Mesokurtic \\
\hline E09 & 197.7 & 201.8 & Fine Sand & 1.60 & $\begin{array}{l}\text { Very Well } \\
\text { Sorted }\end{array}$ & 0.46 & Symmetrical & 1.38 & Mesokurtic \\
\hline E10 & 211.9 & 212.6 & Fine Sand & 1.83 & $\begin{array}{l}\text { Very Well } \\
\text { Sorted }\end{array}$ & 0.66 & Symmetrical & 1.50 & Platykurtic \\
\hline E11 & 235.9 & 239.4 & Fine Sand & 1.90 & $\begin{array}{l}\text { Moderately } \\
\text { Well Sorted }\end{array}$ & 0.42 & Symmetrical & 1.41 & Mesokurtic \\
\hline Average & 228.3 & 226.5 & Average & 1.31 & Average & -0.06 & Average & 0.93 & \\
\hline
\end{tabular}


Table 6

Distribution of sand classes in percentage.

\begin{tabular}{|llll|}
\hline & Medium Sands (percent) & Fine Sands (percent) & Very Fine Sands (percent) \\
\hline E01 & 52.78 & 46.27 & 0.83 \\
\hline E02 & 17.23 & 81.60 & 1.11 \\
\hline E03 & 15.98 & 82.47 & 1.52 \\
\hline E04 & 19.59 & 79.78 & 0.54 \\
\hline E05 & 42.91 & 48.30 & 5.75 \\
\hline E06 & 56.27 & 42.15 & 1.39 \\
\hline E07 & 46.55 & 46.06 & 5.28 \\
\hline E08 & 17.50 & 81.40 & 1.11 \\
\hline E09 & 16.00 & 82.50 & 1.10 \\
\hline E10 & 20.00 & 79.00 & 1.50 \\
\hline E11 & 42.5 & 48.8 & 0.1 \\
\hline Average & 35.90 & 60.95 & 2.34 \\
\hline
\end{tabular}

Morphoscopic analysis of the quartz particles in sediments from the Ksour Mountains identified several forms, including fresh and angular (NU), round mat (RM), and rounded and shiny (EL) quartz grains. The fresh and angular $(\mathrm{NU})$ shape of the grains could result from low transport. The presence of round mat (RM) grains suggests the impact of aeolian transport. The rounded and shiny (EL) grains indicate the long aquatic mechanical mixing probably of hydrological origin. Fig. 7 shows the Scanning Electron Microscopy (SEM) observation of sands of the study area. The preliminary examinations of the sands in our study area showed that 73 percent of sand are in RM category, i.e. round mat grains are frosted and rounded by aeolian transport and it has a high carbonate content 47 percent $\mathrm{CaCo} 3$ and a low percentage in organic matter, silt and clay, from a dynamic point of view, that the wind transport is done mainly by saltation and affects 98 percent of the sand grains, while the deposit is dune. Otherwise, the rounded and shiny (EL) category represents about 19 percent of samples, while 08 percent are represented by the fresh and angular (NU) category, which have undergone low transport. The morphoscopic study of the sands of the research area asserts that the grains of the sands in our study area are blunt and shiny grains with a dominance of rounded edges, and can sometimes acquire the shape of almost perfect spheres. Their surface appearance is always very polished, shiny, gleaming under the light of the binocular magnifying glass. They are characterized by long transports due to an allochthonous origin, with a very high probability. According to Bouarfa and Bellal (2018), the primary winds are from the south and north, with the east and west coming in second and third, from the unidirectional sandy transport regime. Only the winds from the South and WSW sectors are effective and the most frequent, they are capable of generating a sandy displacement.

On the other hand, outside the region we can count outcrops and source areas providing allochthonous sand. Therefore, we suggest that other reservoirs supplying the sands containing large quantities of sand are located on Moroccan territory such as Chott Tigri, Oued Maader, the corridor between Figuig, Bouarfa and Massa Daraa, are the dominant sources of sands in the region of Ksour Mountains. Chott El Gharbi as example covers an area of more than 140,000 ha, and a large part of its supply comes exclusively from Moroccan territory. The entire transit corridor connecting the two Chotts (El Gharbi and Ehergui) is covered by a sandy veil about thirty kilometers wide which gives us very explicit 
information on the passage taken by the sand during its transfer from the South-West (Chott El Gharbi) to the NorthEast (Chott EChergui).

\section{Conclusions}

The region of Ksour Mountains is suffering in many localities from significant aeolian sand deposit problems, which result from the severity of climatic and soil conditions, and the non-rational usage of natural resources constitutes the most spectacular desertification phenomenon. The comprehension of the sand deposit phenomenon was achievable by the combined effect of geological, climatic, edaphic and geomorphological factors. The regional wind transport process plan is sand between source zones and deposit zones. The wind remains the primary element responsible for modeling the landform where the wind regime, including direction, magnitude, and frequency, identifies shape, migration, dynamics, and accumulation of dunes of sands. Granulometric testing of samples from 11 locations showed that sand size was mainly very fine to fine grained, with mean grain value of $226.5 \mu \mathrm{m}$, sorting ranged from 1.22 to 1.90 indicating well sorting of the sands and skewness values ranges from -0.4 to 0.66 , being mainly negative with an average of -0.06 , indicated symmetrical to fine skewed values. The kurtosis values range from 0.79 to 1.5 , with an average of 0.93 , where 64 percent of samples are Mesokurtotic and 36 percent of samples are Platikurtotic. Calcimetric results show a very low carbonate percentage, ranging from 1.85 percent to 7.4 percent, and illustrate a very low fine fraction content and organic matter. The preliminary examinations of the sands in our study area by morphoscopy showed that 73 percent of sand are in RM category, 19 percent in the rounded and shiny (EL) category. In comparison, 08 percent are represented by the fresh and angular (NU) category. The sands of our study area are characterized by long transports due to an allochthonous origin from Moroccan territory, with a very high probability. Despite the success demonstrated, a significant limitation is the lack of prior research studies on the topic in the Moroccan side. Further work to improve on these new developments is suggested. However, selecting the best aeolian sand stabilization method looks to be a difficult process that necessitates a thorough experimental investigation involving a variety of additives as well as other significant variables such as agent quantities and aging duration.

\section{Declarations}

\section{Acknowledgments}

Authors gratefully acknowledge the support of the Centre for Scientific and Technical Research in the Dry Areas (CRSTRA), the Laboratory of Eremology and Combating Desertification (IRA) of Medenine in Tunisia and the General Directorate of Scientific Research and Technological Development (DGRSDT)".

Funding: "The authors received no specifc funding for this work"

Conflicts of Interest: "The authors declare no conflict of interest."

Ethical approval: "The manuscript is not submitted to any other journal before submission to this journal and further not submitted simultaneously to another journal, Hence ethical standards are taken care of "

\section{References}

1. Abuzaid AS, AbdelRahman MA, Fadl ME, Scopa A (2021) Land degradation vulnerability mapping in a newlyreclaimed desert oasis in a hyper-arid agro-ecosystem using AHP and geospatial techniques. J Agronomy 11(7):1426 
2. AFNOR (2018) Geotechnical investigation and testing - Laboratory testing of soil - Part 4: Determination of particle size distribution. Retrieved from

3. Aidoud A, Touffet J (1996) La régression de l’alfa (Stipa tenacissima L.), graminée pérenne, un indicateur de désertification des steppes algériennes. J Science et changements planétaires/Sécheresse 7(3):187-193

4. Baratoux D, Mangold N, Arnalds O, Bardintzeff JM, Platevoet B, Grégoire M, Pinet P (2011) Volcanic sands of Iceland-Diverse origins of aeolian sand deposits revealed at Dyngjusandur and Lambahraun. J Earth surface processes Landforms 36(13):1789-1808

5. Barrena-González J, Rodrigo-Comino J, Gyasi-Agyei Y, Pulido Fernández M, Cerdà A (2020) Applying the RUSLE and ISUM in the Tierra de Barros Vineyards (Extremadura, Spain) to estimate soil mobilisation rates. J Land 9(3):93

6. Beadnell HJL (1909) An Egyptian oasis: an account of the oasis of Kharga in the Libyan desert, with special reference to its history, physical geography, and water-supply. J. Murray

7. Benazzouz MT (2003) A new chronology of upper Holocene Aeolian sands in the Zibans range, Algeria

8. Berthois $L$ (1959) Remarques sur les rides sous-marines: théorie de la formation des rides. J Revue des travaux de I'Institut des pêches maritimes, 23(2)

9. Bertran P, Bosq M, Borderie Q, Coussot C, Coutard S, Deschodt L, Wuscher P (2021) Revised map of European aeolian deposits derived from soil texture data. J Quaternary Science Reviews 266:107085

10. Blake WP (1855) ART. XVI.--On the Grooving and Polishing of hard Rocks and Minerals by dry Sand. J American Journal of Science Arts 20(59):178

11. Blott SJ, Pye K (2001) GRADISTAT: a grain size distribution and statistics package for the analysis of unconsolidated sediments. J Earth surface processes Landforms 26(11):1237-1248

12. Bouarfa S, Bellal SA (2018) Assessment of the Aeolian sand dynamics in the region of Ain Sefra (Western Algeria), using wind data and satellite imagery. J Arabian Journal of Geosciences 11(3):1-16

13. Boulghobra N (2016) Climatic data and satellite imagery for assessing the aeolian sand deposit and barchan migration, as a major risk sources in the region of In-Salah (Central Algerian Sahara). J Arabian Journal of Geosciences 9(6):450

14. Boulghobra N, Koull N, Benzaoui T (2016) Four decades period of climatic data for assessing the aeolian hazard in the region of Touggourt (Low Algerian Sahara).J Geographia Technica, 11(1)

15. Boureboune L, Benazzouz M (2009) Aeolian morphogenesis and strategy of fight against desertification in Algeria (Hodna and Zibans Basin). Desertification and Risk Analysis Using High and Medium Resolution Satellite Data. Springer, pp 91-103

16. Chojnacki M, Fenton LK, Weintraub AR, Edgar LA, Jodhpurkar MJ, Edwards CS (2020) Ancient Martian aeolian sand dune deposits recorded in the stratigraphy of Valles Marineris and implications for past climates. $J$ Journal of Geophysical Research: Planets, 125(9), e2020JE006510.

17. Derdour A, Ali MMM, Sari SMC (2020) Evaluation of the quality of groundwater for its appropriateness for drinking purposes in the watershed of Naâma, SW of Algeria, by using water quality index (WQI). J SN Applied Sciences 2(12):1-14

18. Derdour A, Bouanani A (2019) Coupling HEC-RAS and HEC-HMS in rainfall-runoff modeling and evaluating floodplain inundation maps in arid environments: case study of Ain Sefra city, Ksour Mountain. SW of Algeria. J Environmental Earth Sciences 78(19):1-17

19. Derdour A, Bouanani A, Babahamed K (2018) Modelling rainfall runoff relations using HEC-HMS in a semi-arid region: Case study in Ain Sefra watershed, Ksour Mountains (SW Algeria). J Journal of water and land 
development

20. Derdour A, Guerine L, Allali M (2021) Assessment of drinking and irrigation water quality using WQI and SAR method in Maâder sub-basin, Ksour Mountains, Algeria. J Sustainable Water Resources Management 7(1):1-14

21. Folk RL, Ward WC (1957) Brazos River bar [Texas]; a study in the significance of grain size parameters. J Journal of sedimentary research 27(1):3-26

22. Fotoohi S, Negaresh H, Khatooni D, Bayat M (2022) Investigating aeolian deposits in Hamun Lake located in east of Iran during Holocene period. J Environmental Earth Sciences 81(1):1-17

23. Han Q, Qu J, Liao K, Zhang K, Zu R, Niu Q (2012) A wind tunnel study of the parameters for aeolian sand transport above a wetted sand surface using sands from a tropical humid coastal region of southern China. J Environmental Earth Sciences 67(1):243-250

24. Hereher ME (2018) Geomorphology and drift potential of major aeolian sand deposits in Egypt. J Geomorphology 304:113-120

25. Hulseman J (1966) An inventory of marine carbonate materials. J Journal of Sedimentary Petrology ASCE 36(2):622-625

26. ISO (1998) J Qualité du sol. Dosage du carbone organique par oxydation sulfochromique (ISO 14235:1998)

27. Liu S, Zhang J, Zhang J, Li Z, Geng Y, Guo Y (2021) Assessing Controversial Desertification Prevention Policies in Ecologically Fragile and Deeply Impoverished Areas: A Case Study of Marginal Parts of the Taklimakan Desert, China. J Land 10(6):641

28. Liu X-J, Cong L, An F, Miao X, Chongyi E (2019) Downwind aeolian sediment accumulations associated with lakelevel variations of the Qinghai Lake during the Holocene, Northeastern Qinghai-Tibetan Plateau. J Environmental Earth Sciences 78(1):1-12

29. Mainguet M (2012) Desertification: natural background and human mismanagement. Springer Science \& Business Media

30. McKee ED (1979) A study of global sand seas, vol 1052. US Government Printing Office

31. Muller G, Gatsner M (1971) Neues Jahrbuch für Mineralogie Monatshefte. J Chemical analysis 10:466-469

32. Nedjraoui D, Bédrani S (2008) La désertification dans les steppes algériennes: causes, impacts et actions de lutte. J VertigO 8(1):15

33. Pease PP, Bierly GD, Tchakerian VP, Tindale NW (1999) Mineralogical characterization and transport pathways of dune sand using Landsat TM data, Wahiba Sand Sea, Sultanate of Oman. J Geomorphology 29(3-4):235-249

34. Ribault (1975) L'EXOSCOPIE. METHODE ET APPLICATIONS

35. Tian L, Wu W, Zhou X, Zhang D, Yu Y, Wang H, Wang Q (2019) The Ecosystem Effects of Sand-Binding Shrub Hippophae rhamnoides in Alpine Semi-Arid Desert in the Northeastern Qinghai-Tibet Plateau. J Land 8(12):183

36. Trask PD (1931) Compaction of sediments. J AAPG Bulletin 15(3):271-276

37. Udden JA (1914) Mechanical composition of clastic sediments. J Bulletin of the Geological Society of America 25(1):655-744

38. Veit H, Preusser F, Trauerstein M (2015) The Southern Westerlies in Central Chile during the two last glacial cycles as documented by coastal aeolian sand deposits and intercalating palaeosols. J Catena 134:30-40

39. Verger F (1963) Photographie aérienne et géographie littorale. Paper presented at the Annales de géographie

40. von Richthofen FF (1882) China: Ergebnisse eigener Reisen un darauf gegründeter Studien.[With, Atlas], vol 2. D. Reimer

41. Wentworth CK (1922) A scale of grade and class terms for clastic sediments. J The journal of geology 30(5):377392

Page $12 / 18$ 
42. Wolfe SA, Lian OB (2021) Timing, rates and geomorphic controls on holocene loess and aeolian sand deposition using multiple chronometric methods, southeastern Cordillera, Alberta, Canada. J Aeolian Research 50:100687

43. Wu N, Ge Y, Abuduwaili J (2021) Grain Size Characteristics of Sediments Found in Typical Landscapes in the Playa of Ebinur Lake, Arid Central Asia. J Land 10(11):1132

44. Zhu Z (1985) Status and trend of desertification in northern China. J Journal of desert research 5:3-11

\section{Figures}

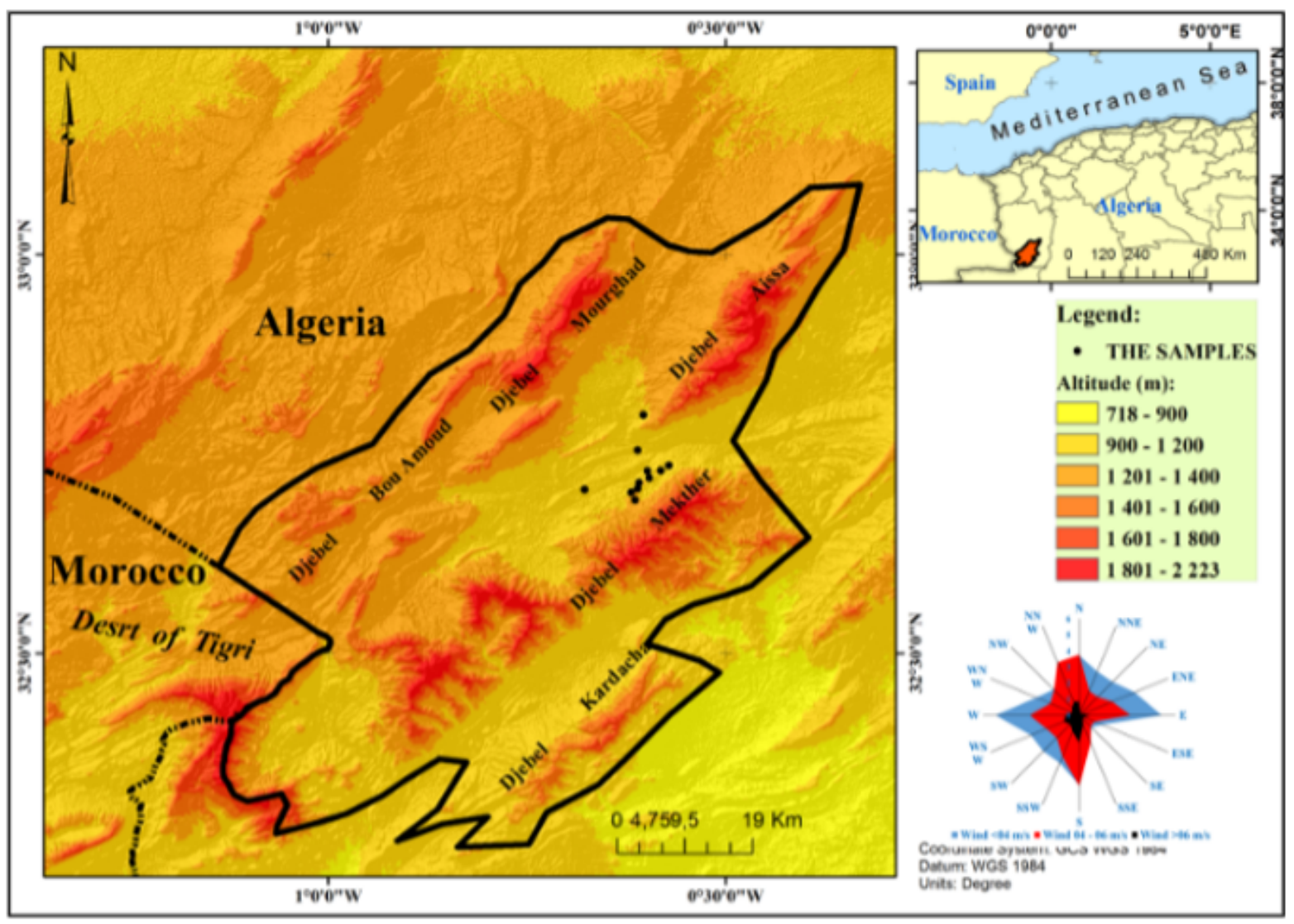

Figure 1

Study area 


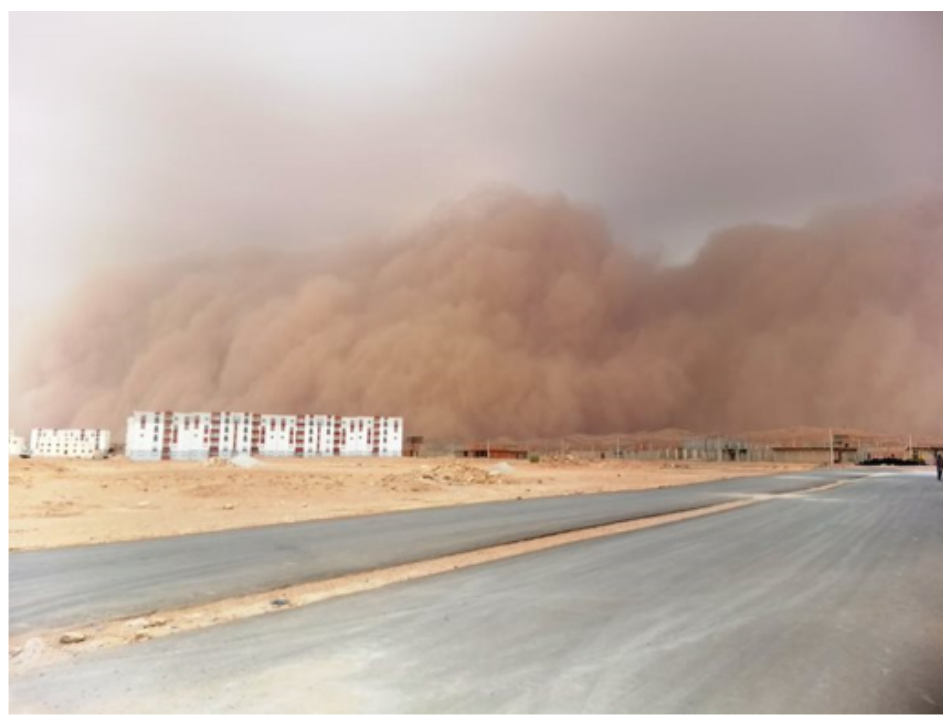

Dust storm in Ain Sefra city (24 May 2021)

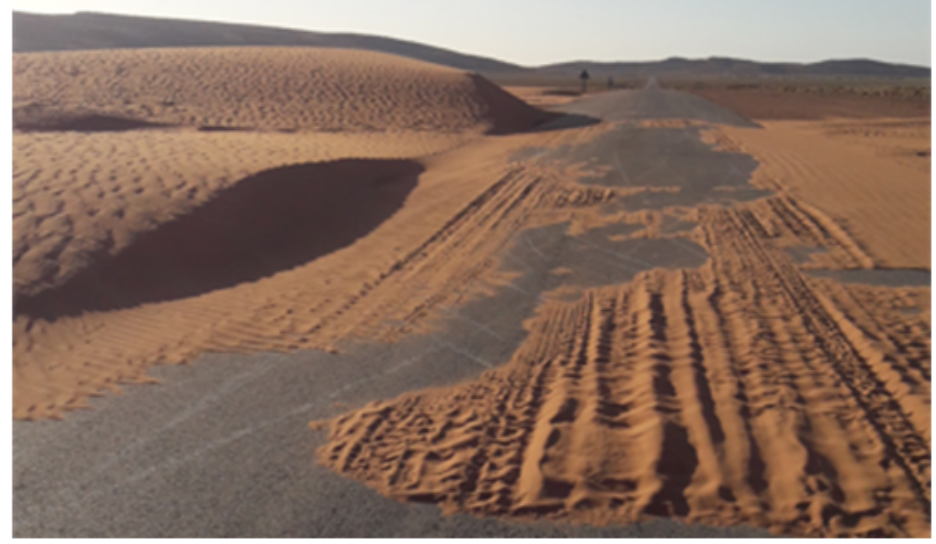

Blowing sands in the road of Ain Sefra (28 May 2021)

\section{Figure 2}

Problems caused by wind-blown sands in Ain Sefra city.

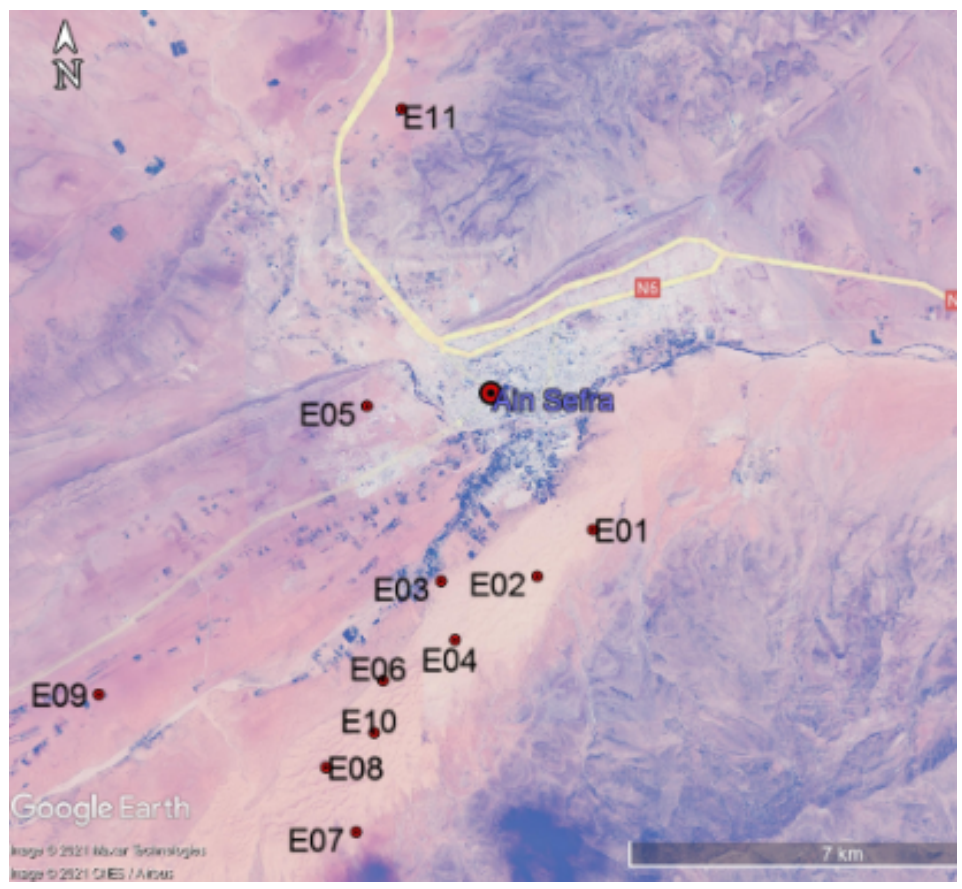

\section{Figure 3}

Sample's location in Ain Sefra. 


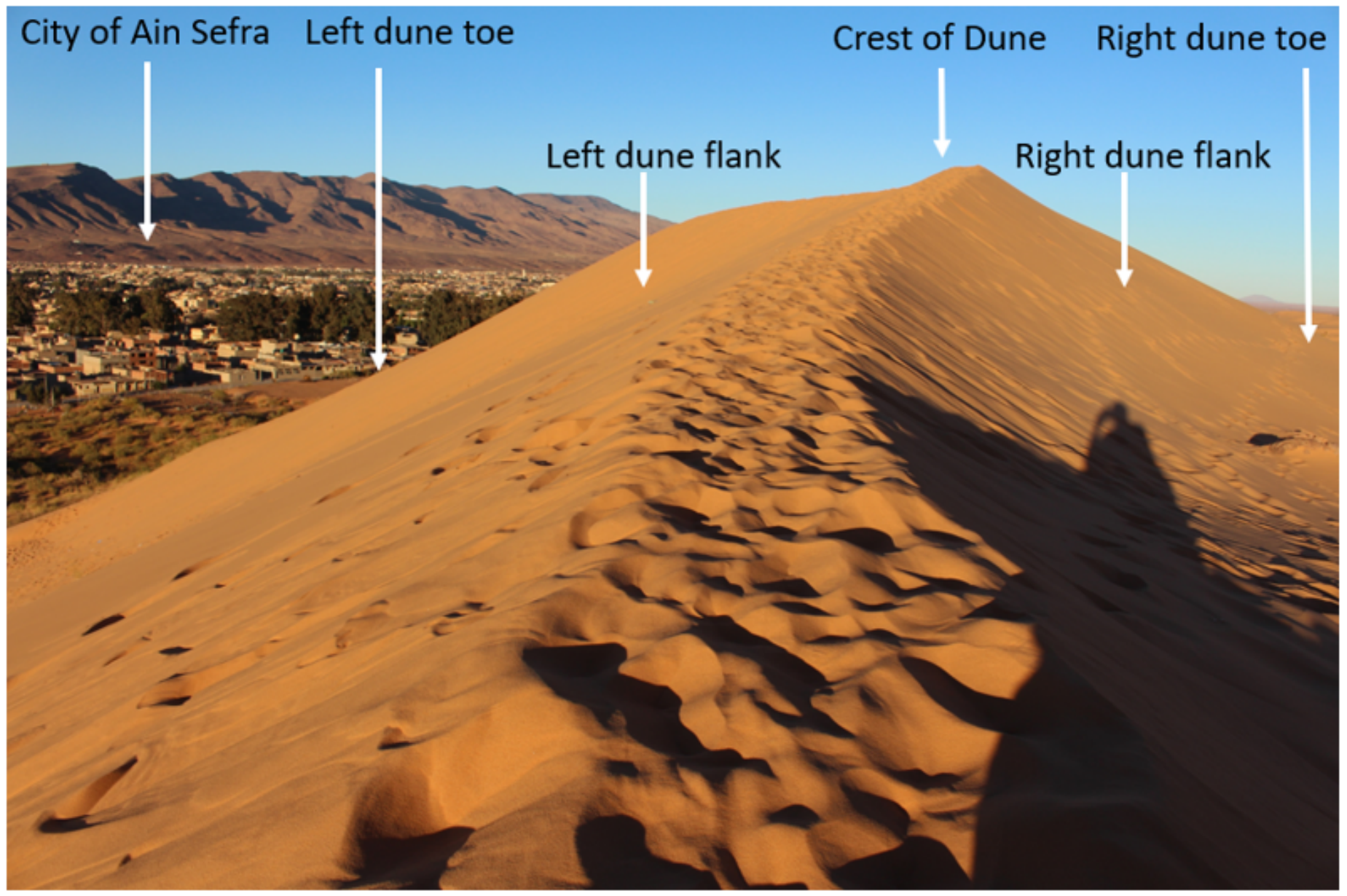

Figure 4

Positions of the samples in the dunes of Ain Sefra. 


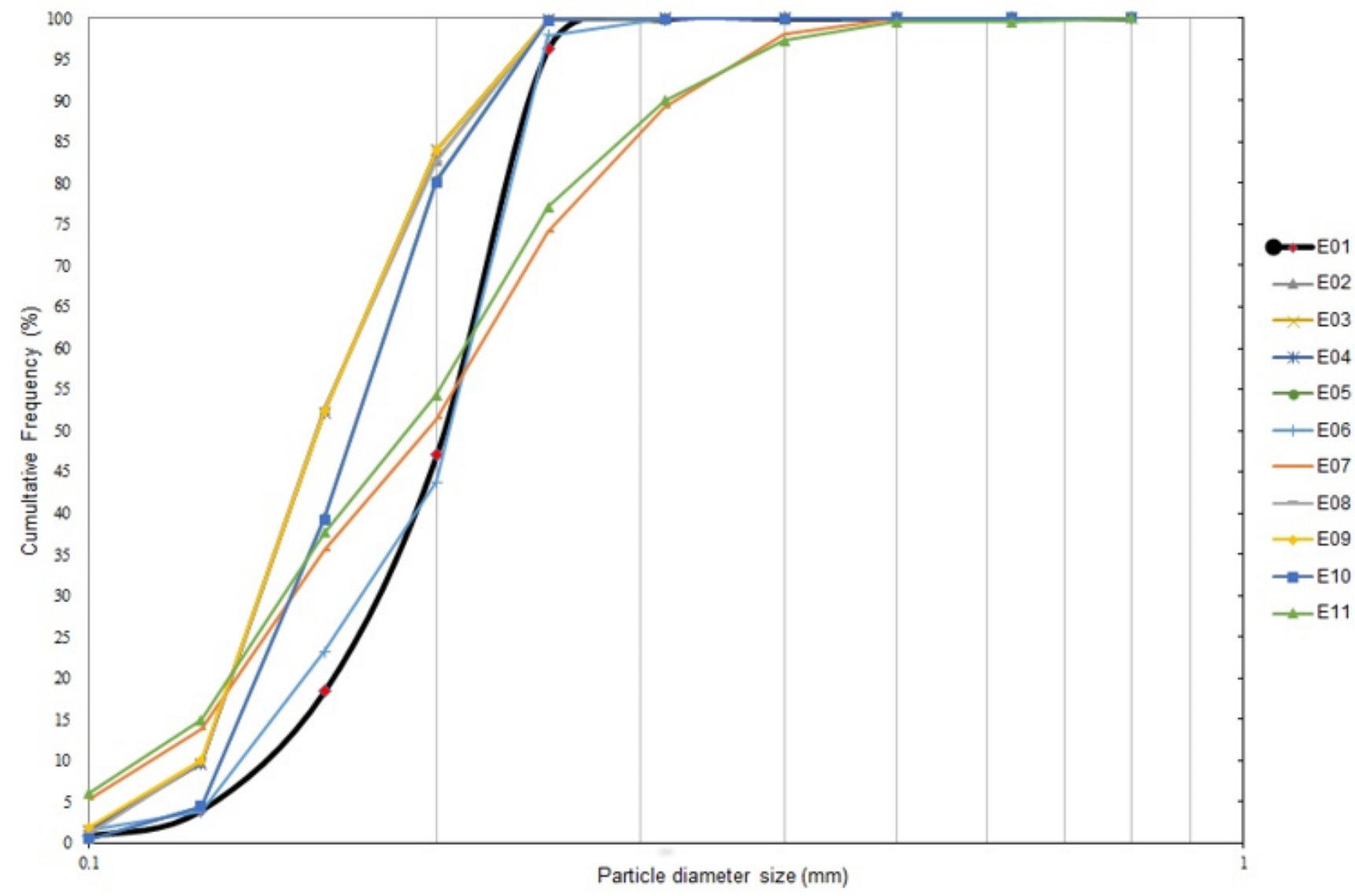

Figure 5

Cumulative curves of samples of sands in the study area. 


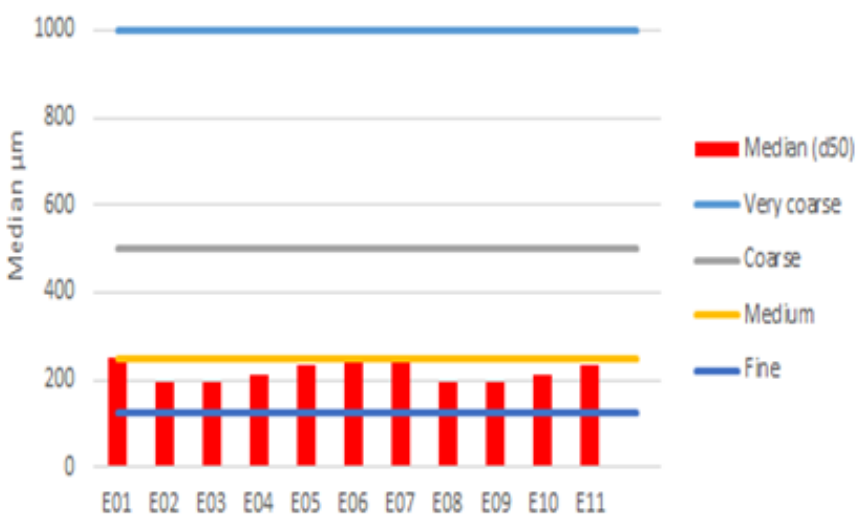

(c)

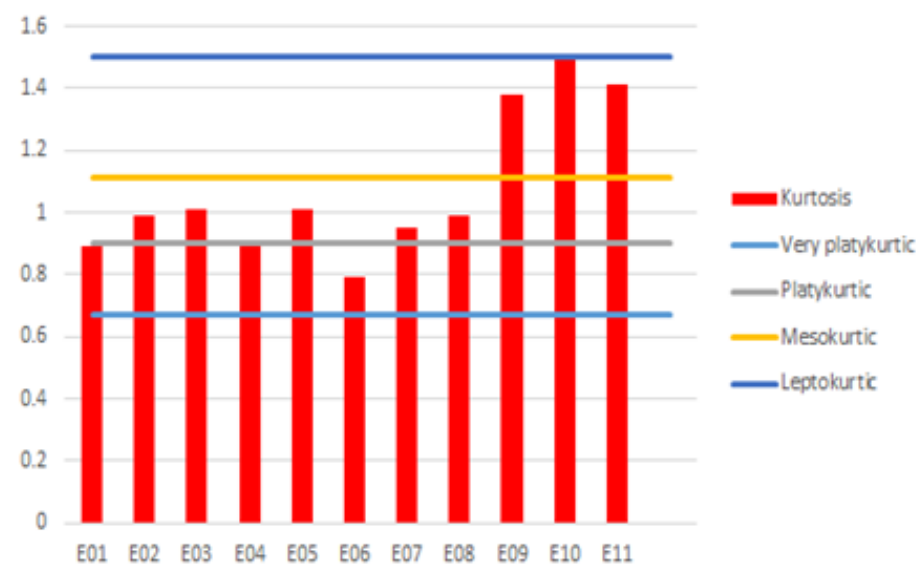

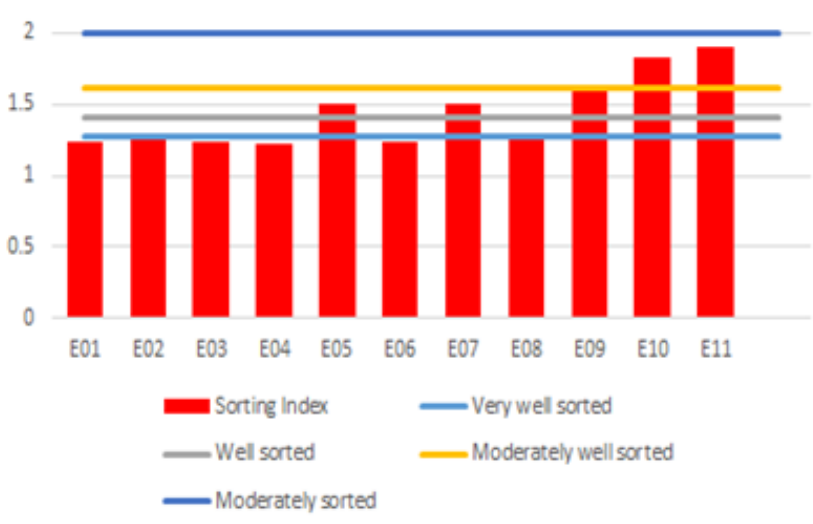

(d)

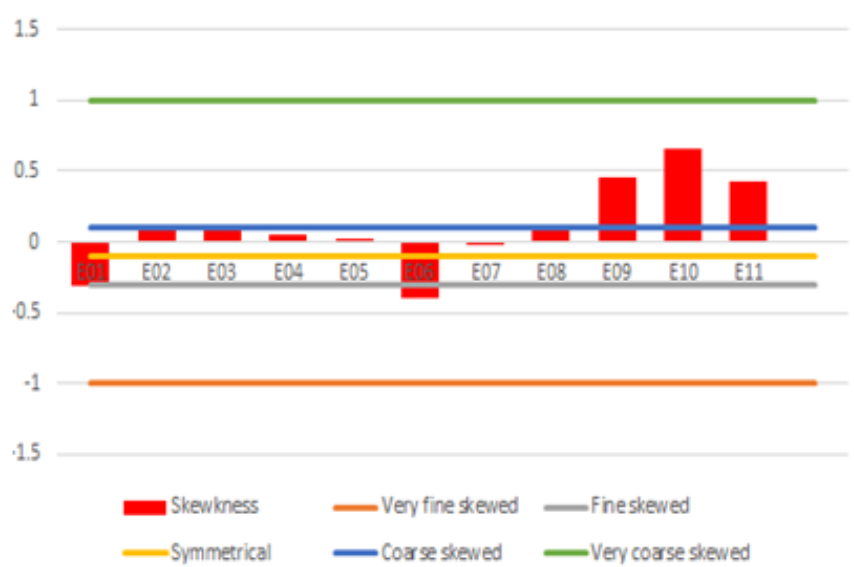

\section{Figure 6}

Histograms of all samples plotted with the respect to statistical parameters calculated by the GRADISTAT program: AMedian, B-Sorting, C-Kurtosis, D-Skewness. 


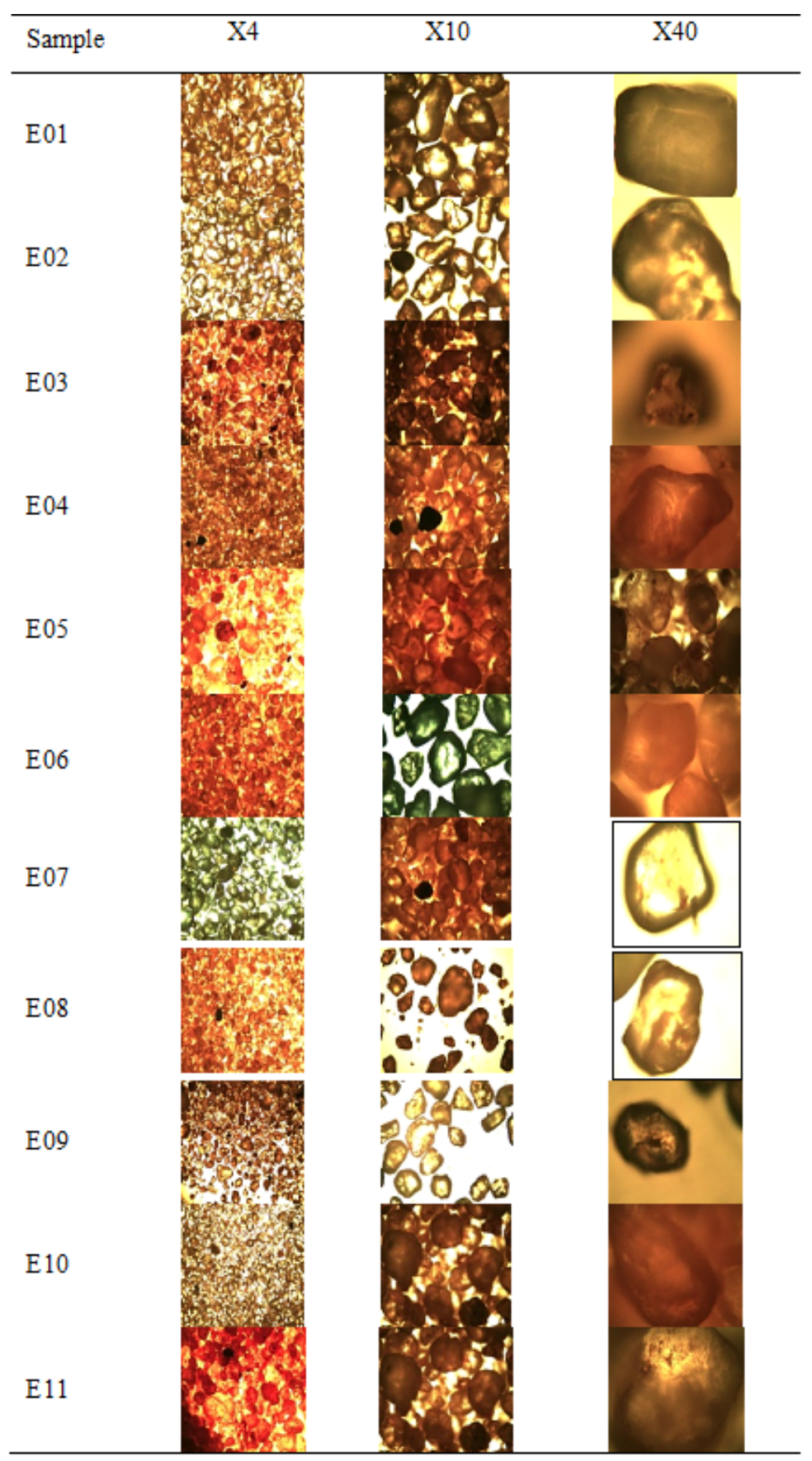

Figure 7

The Scanning Electron Microscopy (SEM) observation of sands of the study area. 